\title{
Hyperbaric Oxygen Influences Chronic Wound Healing - a Cellular Level Review
}

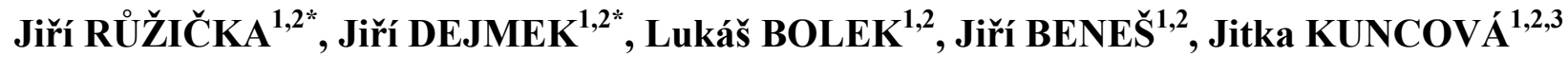 \\ * These authors contributed equally to this work. \\ ${ }^{1}$ Biomedical Centre, Faculty of Medicine in Plzeň, Charles University, Plzeň, Czech Republic, \\ ${ }^{2}$ Institute of Biophysics, Faculty of Medicine in Plzeň, Charles University, Plzeň, Czech Republic, \\ ${ }^{3}$ Institute of Physiology, Faculty of Medicine in Plzeň, Charles University, Plzeň, Czech Republic
}

Received April 22, 2021

Accepted October 14, 2021

\section{Summary}

Chronic wound is a serious medical issue due to its high prevalence and complications; hyperbaric oxygen therapy (HBOT) is also considered in comprehensive treatment. Clinical trials, including large meta-analyses bring inconsistent results about HBOT efficacy. This review is summarizing the possible effect of HBOT on the healing of chronic wound models at the cellular level. HBOT undoubtedly escalates the production of reactive oxygen and nitrogen radicals (ROS and RNS), which underlie both the therapeutic and toxic effects of HBOT on certain tissues. HBOT paradoxically elevates the concentration of Hypoxia inducible factor (HIF) 1 by diverting the HIF-1 degradation to pathways that are independent of the oxygen concentration. Elevated HIF-1 stimulates the production of different growth factors, boosting the healing process. HBOT supports synthesis of Heat shock proteins (HSP), which are serving as chaperones of HIF-1. HBOT has antimicrobial effect, increases the effectiveness of some antibiotics, stimulates fibroblasts growth, collagen synthesis and suppresses the activity of proteolytic enzymes like matrix metalloproteinases. All effects of HBOT were investigated on cell cultures and animal models, the limitation of their translation is discussed at the end of this review.

\section{Key words}

Hyperbaric oxygen - Wound healing • Reactive oxygen and nitrogen species $\bullet$ Hypoxia inducible factor $\bullet$ Heat shock protein

\section{Corresponding author}

J. Růžička, Institute of Biophysics, Faculty of Medicine in Plzeň, Charles University, Alej Svobody 76, 323 00, Plzeň, Czech
Republic. E-mail: jiri.ruzicka@lfp.cuni.cz

\section{Introduction}

Chronic wound is physiologically affected healing due to a disruption of the healing cycle as a result of impaired angiogenesis, innervation, or cellular migration. Chronic wounds of mixed etiologies showed a pooled prevalence of 2.21 per 1,000 population; for chronic leg ulcers the prevalence was estimated at 1.51 per 1,000 population, so it is a serious medical issue (Martinegro et al. 2019). Treatment of chronic wound must be complex. Local treatment consists of debridement and proper dressings along with so-called adjunctive local therapies (Liu et al. 2013), including hyperbaric oxygen therapy (HBOT).

HBOT is a therapeutic inhalation of pure oxygen in a chamber pressurized up to $0.2-0.3 \mathrm{MPa}$, which is equal to submersion up to $10-20 \mathrm{~m}$ into water. In the protocols for chronic wound treatment, daily sessions limited to working days lasting $90 \mathrm{~min}$ for 4-8 weeks are used. Protocols display high inter-workplace variability in the pressure applied and number of sessions used. Moreover, some facilities employ air breaks, i.e. breathing of air instead of oxygen for approximately $5 \mathrm{~min}$ in the middle of treatment, to support vessel contractions (Jain 2009). All these differences can contribute to problematic evaluation of the outcome of HBOT. HBOT has been used in the world (first in the USA) for over 100 years; in the Czech Republic since 
1965 (Emmerová et al. 2007, Kindwal 1994). The spectrum of indications is broad and often criticized for insufficient scientific justification. Apart from divers' accidents, there is not a single diagnosis that has not been criticized for the possible ineffectiveness of the use of HBOT (Gabb et al. 1987). Less controversial diagnoses include non-healing chronic defects that occur with predilection for the lower limbs in patients with diabetes, ischemic disease, or venous insufficiency. The impact of HBOT on so-called diabetic foot syndrome, manifested in non-healing lower limb defect (DFU), has been extensively studied.

Most meta-analyses reported a positive effect of HBOT on DFU, concluding that HBOT reduces the risk of above-knee amputations and improves defect healing, even in one-year follow up (Stoekenbroek et al. 2014, Kranke et al. 2015, Elraiyah et al. 2016). In contrast, another meta-analysis of 6,259 patients did not show any beneficial effect of HBOT (Margolis et al. 2013). In addition, recent randomized clinical trials (Santema et al. 2018, Fedorko et al. 2016) have not shown any positive impact of HBOT on reducing the risk of lower limb amputations or on accelerating DFU healing either.

The reasons for these controversial results are difficulties in clinical trials caused by group inhomogeneity and specific problems with the control group: in principle, HBOT cannot be administered in a placebo regimen, control groups are either not treated at all or undergo modified HBOT in a presumed ineffective regimen. One reason for scepticism about HBOT is the lack of explanation for the effect of HBOT at the cellular level. Therefore, the research is also intensively focused on animal models of chronic wounds and cell cultures (e.g. of skin fibroblasts), where standard experimental conditions can be provided. The aim of this review is to summarize the possible effect of HBOT on the healing of chronic wound models at the cellular level of the repair processes. It will be shown that free oxygen radicals in particular play a complex role in regulation and fundamentally affect the positive and negative effects of HBOT.

\section{Reactive oxygen and reactive nitrogen species}

Reactive oxygen (ROS) and reactive nitrogen species (RNS) are naturally occurring metabolites, mostly with a very short reaction time. ROS include free oxygen radicals and non-radical species, e.g. superoxide anion $\left(\mathrm{O}_{2}^{-}\right)$, hydroxyl radical $\left(\mathrm{OH}^{-}\right)$, hydrogen peroxide $\left(\mathrm{H}_{2} \mathrm{O}_{2}\right)$, singlet oxygen ${ }^{1} \mathrm{O}_{2}$, and many others. Nitric oxide (NO) and peroxynitrite $\left(\mathrm{ONOO}^{-}\right)$are typically referred to as RNS, with some of them being linked to ROS by metabolic pathways. ROS and RNS occur in small amounts during normal metabolism having a signaling role and contributing to pathogen resistance (Pisoschi et al. 2015, Yang and Lian 2020). However, high concentrations of ROS and RNS damage nucleic acids, proteins or lipids (Schieber et al. 2014). Their increased concentration has been observed in about 100 pathological conditions, typically in various inflammatory and reperfusion syndromes (Gutteridge 1993).

Mitochondria are considered to be the major source of ROS, however a number of enzymes, such as xanthine oxidase and NADPH oxidase can catalyse the formation of ROS in the cell cytoplasm. In the chronic wound that frequently suffers from severe hypoxia, ROS are supposed to be generated preferentially out of mitochondria (Stowe and Camara 2009).

During wound healing process, inflammation associated with a recruitment and activation of immune cells is a typical feature. ROS and RNS play an irreplaceable role in phagocytosis, when pathogens are encapsulated by macrophages, neutrophils or dendritic cells. After pathogen internalization, the cells start the process of oxidative burst, when consumption of molecular oxygen increases by activated NADPH oxidases resulting in production of high amounts of ROS that then help in destruction of internalized pathogens. Accumulating evidence suggests that macrophages are dysfunctional in the chronic wounds, not only in the promotion of inflammation, but also in subsequent phases of healing (reviewed in Ganesh and Ramkumar 2020).

Besides direct cytotoxic affects, ROS also interfere with intracellular signaling in a complex way that helps in appropriate timing of individual healing processes (initiation and resolution of inflammation, removal of apoptotic cells and tissue restoration). On the molecular level, ROS are involved in activation MAPK (mitogen-activated protein kinase) pathway, which is a ubiquitous family of serine/threonine kinases playing an essential role in signal transduction from the cell membrane receptors to the nucleus (Brown and Sacks 2009). Specifically in the chronic wounds, MAPK induction makes cells generate signaling proteins like monocyte chemoatracting protein (MCP-1), series of interleukines (IL) IL-1, 8, 6, tumor necrosis factor alpha (TNF $\alpha$ ) and macrophage inflammatory protein (MIP-1). 
This complex protein system stimulates inflammation and attracts phagocytes, neutrophils, eosinophils, basophils and lymphocytes into the wound (Bryan et al. 2012).

ROS also mediate cell division and migration of kerationocytes, endothelial and fibroblast proliferation (Dunnill et al. 2017), they are involved in antigen presentation in dendritic cells through expression of CD86, stimulate CD4 differentiation, release $\mathrm{Ca}$ ions from endoplasmic reticulum into the cytosol resulting in Ca-dependent MAPK signaling and $\mathrm{P}$ selectin expression, which causes adhesion of neutrophils to endothelium. By similar mechanism ROS enable leukocyte extravasation during inflammation. In addition, ROS influence phenotype of fibroblasts stimulating their differentiation into myofibroblasts (Bryan et al. 2012).

HBOT leads to an increased accumulation of ROS through elevated oxygen concentration (Kindwall 1994, Jain 2007) by shifting the reaction potentials towards the formation of ROS. It seems logical that an increase in ROS will lead to oxidative tissue damage. These adverse effects on DNA damage have been documented on leukocytes (Dennong et al. 1996) and have led to the spread of criticism of HBOT as an ineffective and potentially harmful therapy.

However, HBOT was shown to increase ROSinduced mobilization of stem cells to the wound and to contribute to the activation of transcription factors inducing the secretion of growth factors important for wound repair processes (Dunnill et al. 2017). Another ROS-balancing effect of HBOT was documented in the rat model of the chronic wound where NADPH oxidase flavocytochrome b large subunit gp91phox was downregulated in the HBOT environment (Ma et al. 2020, Zhang and Gould 2013).

The cell maintains, or seeks to maintain, a balance between ROS production and their degradation mechanisms that reduce ROS concentration. Increased concentration of ROS induced by HBOT leads to increased activation of antioxidant mechanisms, which might in turn prevent tissue damage. ROS are typically eliminated by the enzymes superoxide dismutase (SOD), catalase (CAT) and glutathione peroxidase (GSH) that have been shown to be up-regulated by HBOT (Cozene et al. 2020, Thom 2009).

RNS are metabolically linked to ROS at several levels. Three enzymes play a major role in the formation of RNS: inducible-, endothelial- and neuronal nitric oxide synthase (i-, e-, n-NOS). The effect of HBOT on the activity of these enzymes is complex. In a chronic wound model in which a higher initial RNS concentration was determined, HBOT was shown to reduce iNOS activity (Zhang and Gould 2013, Poff et al. 2016) and thus to prevent further RNS formation and tissue damage. Conversely, other tissues, such as rat brain, showed higher e-NOS activity under HBOT conditions and increased RNS production (Xu et al. 2009, Elayan et al. 2000).

A high inter-individual variability was found in the effect of HBOT on iNOS activity. Some authors conclude that this could be a possible cause of HBOT ineffectiveness at least in some cases. Others try to find a genomic differences to explain poor response to HBOT. In human patients subjected to HBOT, approximately $25 \%$ of defects did not respond to the treatment (Zhang and Gould 2013, Löndahl et al. 2010). The possibility that this phenomenon is related to the regulation of iNOS activity in the wound should be further explored (Johnston et al. 2016).

In conclusion, HBOT undoubtedly stimulates the production of ROS and RNS, as well as it promotes the activity of antioxidant enzymes thus establishing new balance between pro- and antioxidant mechanisms. In addition, HBOT could have both beneficial and detrimental impact in different tissues. E.g. in the lungs, exposure to high oxygen concentrations (even lower than in HBOT) leads to deposition of collagen, inflammation, diffuse alveolar damage, pulmonary edema, chronic pulmonary fibrosis and emphysema (Mach et al. 2011, Pereira et al. 2014, Thomson and Paton 2014). At the cellular level, lung fibroblasts subjected to HBOT displayed compromised viability and impaired mitochondrial oxygen consumption (Dejmek et al. 2018). It is thus not possible to decide on the unequivocal benefit of HBOT, however it seems that the potential benefit of this adjunctive method in the chronic wound treatment should be further explored.

\section{Hypoxia inducible factor-1}

Hypoxia inducible factor-1 (HIF-1) is a complex of proteins that is activated in conditions of hypoxia, i.e. lower oxygen concentration. The proteins are marked with Greek letters; HIF-1 $\alpha$ is a protein that is responsible for regulating the concentration of the whole complex, therefore, sometimes only HIF-1 $\alpha$ is referred to. HIF-1 is used in many physiological and pathophysiological processes such as embryonic development by promoting formation and differentiation of the vascular and 
hematopoietic systems, inhibition of differentiation of preadipocyte fibroblasts into adipocytes and myoblasts into myocytes, proliferation of some tumors, secretion of inflammatory chemokines, attraction of neutrophils and monocytes in inflammation, etc. HIF-1 regulates the division of stem cells, preventing their rapid differentiation (Takubo et al. 2010, Semenza et al. 1998).

HIF acts in a specific way in chronic wounds, having a crucial role in the healing process. It supports keratinocyte migration and epithelial regeneration. It stimulates the production of vascular endothelial growth factor (VEGF), platelet derived growth factor (PDGF) and stromal cell derived factor (SDF). The migration of endothelial progenitor cells into the wound is controlled also by the SDF pathway (Benizri et al. 2008).

The half-life of HIF degradation is in the order of minutes under normal conditions. The most important pathway of its degradation is hydroxylation (by the enzyme prolyl hydroxylase) and subsequent binding to the von Hippel Lindau tumor suppressor protein (vHL).
This complex is then destroyed by the protease system. The degradation, or the binding of HIF-1 to vHL is dependent on the oxygen concentration (Zepeda et al. 2013). More precisely, this binding is controlled by redox changes upstream from complex IV of mitochondrial respiratory chain (Stowe and Camara 2009). Therefore a higher HIF level is achieved (by this mechanism) under hypoxic conditions, where the protein is synthesized but not degraded. Under conditions of hypoxia, HIF-1 binds to other hypoxia responsive elements and promotes the synthesis of VEGF, SDF and PDGF.

There are other mechanisms of HIF-1 degradation than by the vHL pathway, for example via the activated protein kinase $\mathrm{C}$ receptor (RACK1), or through the oxygen-independent E3 ubiquitin ligase pathway (Liu et al. 2007, Isaacs et al. 2002). None of these pathways is dependent on oxygen concentration; on the contrary, they are affected by the expression of heat shock proteins. Degradation of HIF-1 is summarized in Figure 1.

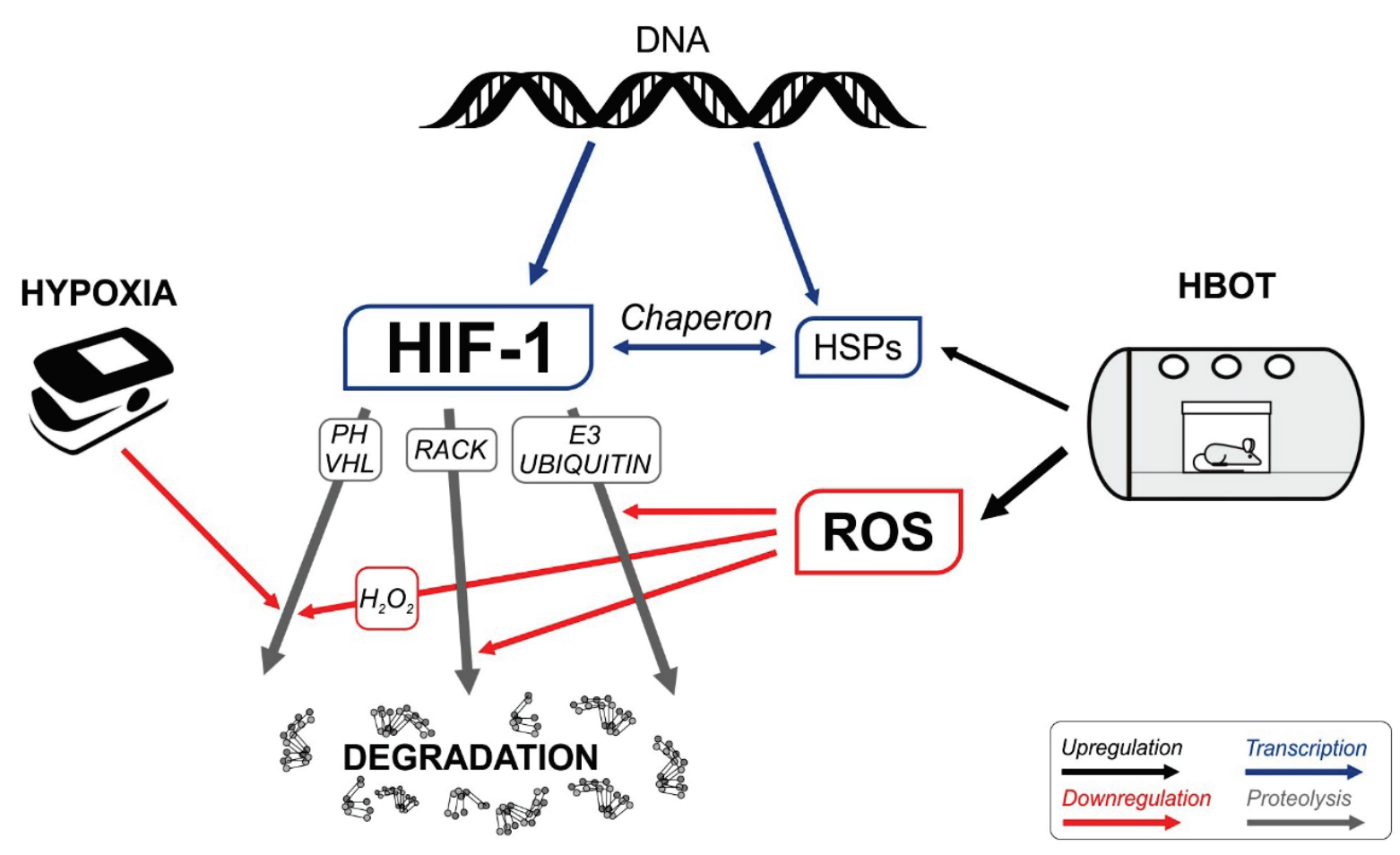

Fig. 1. Regulatory chain of HIF-1 signal protein degradation in relation to HBOT, ROS, HSPs and hypoxia. HIF-1 hypoxia inducible factor-1; HSPs heat shock proteins; PH VHL degradation pathway via prolyl hydroxylases and von Hippel Lindau tumor suppressor protein; RACK, E3 UBIQUITIN degradation pathways through activated protein kinase C receptor and E3 ubiquitin ligase; up- and downregulations are color-coded. Hypoxia directly stimulates HIF-1 gene expression, degradation of which is also oxygen dependent via $\mathrm{PH}$ vHL pathway. Other degradation pathways (RACK, E3 ubiquitin ligase) are oxygen-independent; however, they seem to be inhibited by ROS. HBOT does not interfere with HIF-1 synthesis, but it might contribute to its stabilization, not only through ROS-regulated pathways, but also via activation of HSP binding to HIF-1 that further stabilizes HIF-1 thereby increasing its intracellular levels.

It seems paradoxical that the concentration of HIF-1 could be up-regulated by HBOT, logically the opposite would be expected. HBOT has been shown to comprehensively affect HIF-1 metabolism in human skin 
fibroblast cultures (Sunkari et al. 2015). Immediately after HBOT exposure, HIF destabilization is observed, presumably through activated oxygen-dependent vHL degradation. About $4 \mathrm{~h}$ after HBOT initiation, there is an increase in HIF-1, VEGF and SDF levels. This phenomenon probably means that the degradation of HIF is, in addition to the oxygen concentration, also dependent on ROS (Isaacs et al. 2002, Sunkari et al. 2015). Under conditions of hypoxia, ROS are overproduced and thus the degradation of HIF-1 by the vHL pathway is partially blocked. ROS production is also increased in HBOT, as explained above. Another possible explanation for HIF stabilization under HBOT conditions the degradation block by binding to heat shock proteins.

\section{Heat Shock Proteins}

Heat shock proteins (HSP) represent a group of proteins generally responsible for the cell's response to stress, not just thermal stress. They are massively synthesized in inflammation and intoxication. HSP are denoted by numbers corresponding to their atomic weight in $\mathrm{kD}$ (kilodaltons). They serve as chaperones - they bind to older proteins and help their proteolysis, aggregation of other proteins, their secretion outside the cell, etc. (De Maio 1999, Santoro 2000, Borges and Ramos 2005).

HSP 90 is one of the most studied HSPs, reaching almost 1 percent of the concentration of all cellular proteins (Dzialoszynski et al. 2016). HSP 90 is involved in metabolism even under normal conditions, not only in stress, when it functions in many signaling pathways as a chaperone, i.e. it allows the participation of other proteins in the reaction. It is involved in the control of the steroid and dioxin receptor. Several protein kinases, including the Src and Raf components of the mitogen-activated protein kinase system, are also bound to HSP 90 (Pratt 1997). Src and Raf kinases belong to a group of so-called oncogenes, where Src is involved in tyrosine residues phosphorylation, while Raf is involved in serine and threonine residues phosphorylation. HSP 90 plays a role in the activation of steroid hormones, has metabolic effects in tumors, CNS injuries, neurodegenerative and other diseases (Tran and Frost 2003, Slimen et al. 2014).

HSP 90 is referred to as the HIF-1 chaperone, as shown in Figure 1. The activity of HIF-1 is thus directly conditioned by the presence of HSP 90. When it is blocked, HIF-1 is inactive, which has been repeatedly demonstrated on cell cultures (Minet et al. 1999, Sunkari
2015, Pratt 1997).

Inhibition of HSP 90 degrades HIF-1 by a pathway different from vHL, e.g. by the RACK1 pathway. Conversely, this pathway is repressed when HSP 90 is expressed, which competes for binding to HIF-1 (Liu et al. 2007).

The importance of HSP 90 for chronic wound healing was reviewed elsewhere (Guo et al. 2017). Briefly, HSP $90 \alpha$ protein is deposited into the wound bed and increases motility of skin cells needed for successful healing process (keratinocytes, dermal fibroblasts and endothelial cells) even under conditions of hyperglycemia that causes HIF-1 destabilization. The precise source of HSP 90 should be further explored (skin cells, immune cells).

Only scarce data are available on the effect of HBOT on HSP expression or metabolism in general and in relation to chronic wound healing in particular. It has been documented that hyperbaric oxygen improves the tolerance to decompression sickness probably via increased expression of HSPs $(27,70,90)$ in the rat lungs and spinal cord (Huang et al. 2014, Ni et al. 2013) or alleviates the symptoms of altitude sickness in a rat model, where overexpression of HSP 70 was documented (Wu et al. 2018). Another effect of HBOT on HSP 90 function was described in the rat heart subjected to shortterm pre-exposure to hyperbaric oxygen before the onset of myocardial ischemia and reperfusion, where increased association of HSP 90 with NOS contributed to increased cardioprotection (Cabigas et al. 2006).

In conclusion, potentially beneficial HSP-related effect of HBOT on chronic wound healing should be further studied in relation to putative stabilization of HIF-1, subsequent secretion of VEGF, SDF and PDGF, i.e. stimulation of the healing process.

\section{Antimicrobial effects}

Chronic wound suffers from hypoxia and circulatory disorders. It has weakened natural immune protection and it is therefore regularly colonized or infected by various bacterial strains (Rahim et al. 2017). The possible antimicrobial effects of HBOT have been reviewed recently and comprise both direct and indirect mechanisms (Memar et al. 2019).

The increase in oxygen concentration per se is believed to be directly toxic to anaerobic microorganisms, typically Clostridia strains (Montrief et al. 2019). ROS and RNS, production of which is 
stimulated by HBOT, react spontaneously with pathogen organelles, oxidize their proteins and lipids and irreversibly damage them (Cabiscol et al. 2000, Ezraty et al. 2017). In addition, HBOT promotes protection against bacteria via transient suppression of inflammatory signaling pathways and proinflammatory cytokines expression and release, e.g. from macrophages. It has been documented that the release of interleukins (IL) 1, 6, 8 and tumor necrosis factor $\alpha(\mathrm{TNF} \alpha)$ by circulating monocytes can be compromised by HBOT (Al-Waili and Butler 2006, Weisz et al. 1997, Rinaldi et al. 2011) while anti-inflammatory cytokine IL-10 production is elevated (Pan et al. 2013). HBOT also promotes phagocytosis by leukocytes (Almzaiel et al. 2013), as demonstrated in the neutrophil model - HLA 60 cells. The same study showed an increase in the respiratory burst activity of neutrophil-like cells after HBOT.

HBOT increases the effectiveness of some antibiotics, such as cefazolin, ciprofloxacin, tobramycin, vancomycin and linezolid (Mendel et al. 1999, Kolpen et al. 2017, Lerche et al. 2017, Kurt et al. 2015, Koomanachi et al. 2011). In the study of Gupta et al. (2016), the authors tested fourteen antibiotics against common pathogens Pseudomonas aeruginosa, Klebsiella pneumoniae and Staphylococcus aureus in different oxygen environments, from anoxic to hyperbaric conditions. They concluded that oxygen improved susceptibility to majority of antibiotics evaluated. In addition, this effect significantly correlated with the growth capability of the bacteria studied. One of suggested mechanism of HBOT-induced enhanced sensitivity to antibiotics is revitalization of the dormant bacteria by inducing aerobic metabolism (Jensen et al. 2019).

The antimicrobial effect of HBOT has been documented not only for lower limb defects, but especially for deadly soft tissue infections such as Fournier gangrene (Anheuser et al. 2018, Wilkinson and Doolete 2004). Furthermore, HBOT could be considered as a supportive treatment for some antibiotic-resistant pathogens as it has been shown to inhibit the division of methicillin-resistant Staphylococcus aureus - MRSA (Kurt et al. 2015).

It thus cannot be excluded that in the chronic wounds suffering from severe hypoxia, HBOT through direct and indirect toxic effects of oxygen along with recovery of aerobic metabolism of colonizing bacteria leading to enhanced bactericidal activity of antibiotics might improve the healing process.

\section{Further effects of HBOT in chronic wounds}

Chronic wound is characterized by tissue loss, given by excessive matrix degradation. This process is caused by the up-regulation of proteolytic enzymes, typically matrix metalloproteinases (MMPs). MMPs are a complex group of enzymes, numbered 1 to 19 . According to the substrate, they are further divided into groups of collagenases, gelatinases, stromelysins and membrane-type MMPs (Bode and Maskos 2003, Maskos and Bode 2003). MMPs have natural inhibitors of their function, called the tissue inhibitor of MMPs (TIMPs) (Snoek-van Beurden et al. 2005). Activity of MMPs is regulated primarily by MAPK pathway that is tightly linked to ROS production. MMPs production might be increased by activation of c-Jun N-terminal kinase (JNK) and extracellular signal-regulated kinases $1 / 2$ (ERK1/2) members of MAPK families (Han et al. 2001). MMPs downregulation is mediated by TIMPS, activity of which is stimulated by HBOT.

In a rat chronic wound model, HBOT was shown to reduce MMP1, 2 and 8 expression and activity from day 7 of treatment, while MMP9 was reduced as early as day 3 of HBOT. From day 3 of treatment, TIMP2 expression also increased. Histological analysis of the wound tissue identified MMPs mainly in macrophages and fibroblasts (Zhang and Gould 2013).

In human dermal fibroblast cultures, HBOT has been shown to increase fibroblast proliferation, however, not from the beginning of the treatment but from day 7 of therapy. HBOT further increases the production of the basal growth factor of fibroblast, VEGF and transforming growth factor $\beta 1$ (Kang et al. 2004, Kunnavatanna et al. 2005). Similarly, HBOT promotes the growth of human keratinocyte cultures (Hollander 2000) and neovascularization by stimulating release of growth factors, as discussed in the previous chapters.

Last, but not least, HBOT ameliorates collagen production in chronic wound. On the model of chronic wound in diabetic rat with ischemia delayed collagen deposition was found, especially when hyperglycemia was combined with ischemia. HBOT significantly counteracted these negative effects on collagen deposition, most successfully in animals with ischemia and normoglycemia together (André-Lévigne et al. 2016). This was the only one study in vivo, but more studies in vitro documented that skin fibroblast cultures produced more collagen under condition of HBOT (Huang et al. 2020, Gould and May 2016, Brismar et al. 
1997, Conconi et al. 2003, Modarressi et al. 2010, Kang et al. 2004).

All these phenomena in combination might contribute to acceleration in wound healing with HBOT via prevention of tissue degradation and promotion of its repair. The question is whether the commonly used clinical set-up in medicine, i.e. a maximum of 20-30 treatment exposures, is sufficient. It is possible the effect would only occur with an even greater number of exposures.

\section{Conclusions and Limitation}

To conclude, HBOT enhances ROS and RNS production, which damage certain tissues and organs. On the contrary, ROS and RNS seem to have a positive effect on pathways accelerating the healing of chronic wound. This claim, based on animal and cell culture experiments, should be commented on with the following limitations.

Interpretation of the cell culture experiments is associated with the difficulty of inducing suitable experimental conditions (Place et al. 2017). Merely induction of normoxia for individual cell types is a complicated task. It appears that the oxygen partial pressure $\left(\mathrm{pO}_{2}\right)$ corresponding to the physioxia ranges between 1 to $13 \mathrm{kPa}$, whereas current in vitro experimentations are usually performed in $18.8 \mathrm{kPa}$ of $\mathrm{pO}_{2}$. It is important to realize that most of the experiments performed in so-called normoxia might be dangerously misleading, especially as control to HBOT (Carreau et al. 2011). In HBOT, the situation is worse, complicated by the determination of the real amount of dissolved oxygen. The value of oxygen solubility for clear water is significantly different from inhomogeneous media, such as plasma or culture solutions. Weak interactions between oxygen and water are disrupted by the presence of charged electrolytes and proteins, which form much stronger interactions with water. The Henry constant for these liquids then depends not only on $\mathrm{pO}_{2}$, but also on the concentration of electrolytes, proteins and the temperature of the solution. The value can only be roughly estimated using experimentally derived values of equilibrium dissolved oxygen (Place et al. 2017). Oxygen solubility is similar in most commercially available culture media for human cell lines. Their ionic strength (the sum of all electrically charged particles present in the solution) is in the range of $150-200 \mathrm{mmol} / \mathrm{l}$, equivalent to the average ionic strength of human plasma (Wagner et al. 2011). At an ambient temperature of $37^{\circ} \mathrm{C}$, an atmospheric air pressure of $101.08 \mathrm{kPa}(760 \mathrm{~mm} \mathrm{Hg})$ in the incubator $\left(37^{\circ} \mathrm{C}, 100 \%\right.$ relative humidity, $5 \% \mathrm{CO}_{2}$ ), the oxygen partial pressure above the medium level is $18.8 \mathrm{kPa}$. The theoretical extrapolated concentration of dissolved oxygen in the medium under these conditions is $0.194 \mathrm{mmol} / \mathrm{l}$ (Koppenol and Butler 1985). The values of dissolved oxygen in the culture medium after HBOT are expected to be higher, unfortunately they have not been determined experimentally yet. The time that is required to fully equilibrate the medium varies with the external oxygen concentration and is mostly longer than $3 \mathrm{~h}$ in most experiments, which is much longer than the normal intermittent exposure of the patient. In conclusion, the study of the effect of HBOT on isolated cell lines must be taken with caution, because the values of dissolved oxygen in the culture medium are much higher than the real physiological values, even in the case of control cell culturing in incubator.

Another complication is the interpretation of animal experiments. Lack of optimal preclinical animal models that are capable of properly simulating human chronic wounds still remains a significant translational issue. Animals do not develop chronic wounds in a way that closely resembles those arising in humans. Animal wounds heal faster, with contraction, differ in microbiome, do not create hypertrophic scars or keloids, skin is in the hair etc. Animals do not present the same pathology in metabolism, which is usually the cause of healing problems in human patients. As a most suitable model of Type 2 diabetes serve obese ob/ob mouse (leptin receptor deficient), $\mathrm{db} / \mathrm{db}$ mouse (a point mutation in the leptin receptor gene), NONcNZO10 mouse, and Zucker fa/fa rat with leptin receptor defect (Grada et al. 2018, Fang et al. 2010). Unfortunately, none of the cited articles in this review used such model, as the authors are mostly using the common Type 1 diabetes induced by streptozocin. However, patients suffering from the Type 1 diabetes don't exhibit non healing wounds as frequently as the Type 2 diabetics since they are not impaired by insulin resistance (Apelqvist 2008, Rasmussen et al. 2017).

And finally, timing of the treatment is a problem. Studies made on animal models and on cell cultures have a clear design and compact HBOT intervention, on a certain number of consecutive days, contrary to clinical use. Every clinical study and meta-analysis cited in this review had HBOT intervention 
only on working days. According to the authors' best knowledge, there are no hyperbaric centers in the Czech Republic nor in other European countries that would treat chronic indications on the weekends. The majority of hyperbaric centers are private, some of them don't offer treatment even in acute indications (CO poisoning, anaerobic infections, etc.) (Jain 2009). This is due to the complicated logistics of treatment: patients should be transported somehow to the center, treatment is challenging for staff resources, and patients often do not complete treatment even in the common working day regime of HBOT. For example, in the most recent randomized prospective multi-center trial (Santema et al. 2018), only 39 patients finished treatment out of 60 patients enrolled in this study. And according to the authors' experience, the daily reality of non-study enrolled patients is much worse. All of this can substantially reduce the outcome of possible effective therapy.

We believe further research will clarify the aforementioned problems and limitations.

\section{Conflict of Interest}

There is no conflict of interest.

\section{Acknowledgements}

Study referenced in this review was supported by project No. CZ 02.1.01/0.0/0.0/16-019/0000787 Fighting INfection Diseases, financed from EFRR and by program PROGRES Q39.

\section{References}

ALMZAIEL AJ, BILLINGTON R, SMERDON G, MOODY AJ: Effects of hyperbaric oxygen treatment on antimicrobial function and apoptosis of differentiated HL-60 (neutrophil-like) cells. Life Sci 93: 125-131, 2013. https://doi.org/10.1016/j.1fs.2013.06.003

AL-WAILI NS, BUTLER GJ: Effects of hyperbaric oxygen on inflammatory response to wound and trauma: Possible mechanism of action. Sci World J 6: 425-441, 2006. https://doi.org/10.1100/tsw.2006.78

ANDRÉ-LÉVIGNE D, MODARRESSI A, PIGNEL R, BOCHATON-PIALLAT ML, PITTET-CUÉNOD B: Hyperbaric oxygen therapy promotes wound repair in ischemic and hyperglycemic conditions, increasing tissue perfusion and collagen deposition. Wound Repair Regen 24: 954-965, 2016. https://doi.org/10.1111/wrr.12480

ANHEUSER P, MÜHLSTÄDT S, KRANZ J, SCHNEIDEWIND L, STEFFENS J, FORNARA P: Significance of hyperbaric oxygenation in the treatment of Fournier's gangrene: A comparative study. Urol Int 101: 467-471, 2018. https://doi.org/10.1159/000493898

APELQVIST J: The foot in perspective. Diab Metab Res Rev 24 (Suppl 1): S110-S105, 2008. https://doi.org/10.1002/dmrr.834

BENIZRI E, GINOUVÈS A, BERRA E: The magic of the hypoxia-signaling cascade. Cell Mol Life Sci 65: 1133-1149, 2008. https://doi.org/10.1007/s00018-008-7472-0

BODE W, MASKOS K: Structural basis of the matrix metalloproteinases and their physiological inhibitors, the tissue inhibitors of metalloproteinases. Biol Chem 384: 863-872, 2003. https://doi.org/10.1515/BC.2003.097

BORGES JC, RAMOS CH: Protein folding assisted by chaperones. Protein Pept Lett 12: 257-261, 2005. https://doi.org/10.2174/0929866053587165

BRISMAR K, LIND F, KRATZ G: Dose-dependent hyperbaric oxygen stimulation of human fibroblast proliferation. Wound Repair Regen 5: 147-150, 1997. https://doi.org/10.1046/j.1524-475X.1997.50206.X

BROWN MD, SACKS DB: Protein scaffolds in MAP kinase signalling. Cell Signal 21: 462-469, 2009. https://doi.org/10.1016/j.cellsig.2008.11.013

BRYAN N, AHSWIN H, SMART N, BAYON Y, WOHLERT S, HUNT JA: Reactive oxygen species (ROS)-a family of fate deciding molecules pivotal in constructive inflammation and wound healing. Eur Cell Mater 24: 249-265, 2012. https://doi.org/10.22203/eCM.v024a18

CABIGAS BP, SU J, HUTCHINS W, SHI Y, SCHAEFER RB, RECINOS RF, NILAKANTAN V, KINDWALL E, NIEZGODA JA, BAKER JE: Hyperoxic and hyperbaric-induced cardioprotection: role of nitric oxide synthase 3. Cardiovasc Res 72: 143-151, 2006. https://doi.org/10.1016/j.cardiores.2006.06.031

CABISCOL E, TAMARIT J, ROS J: Oxidative stress in bacteria and protein damage by reactive oxygen species. Int Microbiol 3: 3-8, 2000. 
CARREAU A, HAFNY-RAHBI BE, MATEJUK A, GRILLON C, KIEDA C: Why is the partial oxygen pressure of human tissues a crucial parameter? Small molecules and hypoxia. J Cel Mol Med 5: 1239-1253, 2011. https://doi.org/10.1111/j.1582-4934.2011.01258.x

CONCONI MT, BAIGUERA S, GUIDOLIN D, FURLAN C, MENTI AM, VIGOLO S, BELLONI AS, PARNIGOTTO PP, NUSSDORFER GG: Effects of hyperbaric oxygen on proliferative and apoptotic activities and reactive oxygen species generation in mouse fibroblast 3T3/J2 cell line. J Investig Med 51: 227-232, 2003. https://doi.org/10.1136/jim-51-04-24

COZENE B, SADANANDAN N, GONZALES-PORTILLO B, SAFT M, CHO J, PARK YJ, BORLONGAN CV: An extra breath of fresh air: Hyperbaric oxygenation as a stroke therapeutic. Biomolecules 1279: 2020. https://doi.org/10.3390/biom10091279

DE MAIO A: Heat shock proteins: facts, thoughts, and dreams. Shock 11: 1-12, 1999. https://doi.org/10.1097/00024382-199901000-00001

DEJMEK J, KOHOUTOVÁ M, KRIPNEROVÁ M, ČEDÍKOVÁ M, TƯMA Z, BABUŠKA V, BOLEK L, KUNCOVÁ J: Repeated exposure to hyperbaric hyperoxia affects mitochondrial functions of the lung fibroblasts. Physiol Res 67 (Suppl 4): S633-S643, 2018. https://doi.org/10.33549/physiolres.934046

DENNOG C, HARTMANN A, FREY G, SPEIT G: Detection of DNA damage after hyperbaric oxygen (HBO) therapy. Mutagenesis 11: 605-609, 1996. https://doi.org/10.1093/mutage/11.6.605

DUNNILL C, PATTON T, BRENNAN J, BARRETT J, DRYDEN M, COOKE J, LEAPER D, GEORGOPOULOS NT: Reactive oxygen species (ROS) and wound healing: the functional role of ROS and emerging ROS-modulating technologies for augmentation of the healing process. Int Wound J 14: 89-96, 2017. https://doi.org/10.1111/iwj.12557

DZIALOSZYNSKI TM, MILNE KJ, TREVITHICK JR, NOBLE EG: Heat shock protein concentration and clarity of porcine lenses incubated at elevated temperatures. Mol Vis 22: 1309-1317, 2016.

ELAYAN IM, AXLEY MJ, PRASAD PV, AHLERS ST, AUKER CR: Effect of hyperbaric oxygen treatment on nitric oxide and oxygen free radicals in rat brain. $\mathrm{J}$ Neurophysiol 83: 2022-2029, 2000. https://doi.org/10.1152/jn.2000.83.4.2022

ELRAIYAH T, TSAPAS A, PRUTSKY G, DOMECQ JP, HASAN R, FIRWANA B, NABHAN M, PROKOP L, HINGORANI A, CLAUS PL, STEINKRAUS LW, MURAD MH: A systematic review and meta-analysis of adjunctive therapies in diabetic foot ulcers. J Vasc Surg 63 (2 Suppl): 46S-58S.e1-2, 2016. https://doi.org/10.1016/j.jvs.2015.10.007

EMMEROVÁ M, HADRAVSKÝ M, KRÁTKÝ M, RŮŽIČKA J, BERKOVÁ E, PATEJDLOVÁ I, HAJŠMANOVÁ M: Vznik oboru hyperbarická medicína a oxygenoterapie v České republice a jeho význam v současné humánní medicíně. (Article in Czech) Pracov Lek 59: 27-34, 2007.

EZRATY B, GENNARIS A, BARRAS F, COLLET JF: Oxidative stress, protein damage and repair in bacteria. Nat Rev Microbiol 15: 385-396, 2017. https://doi.org/10.1038/nrmicro.2017.26

FANG RC, KRYGER ZB, BUCK DW 2ND, DE LA GARZA M, GALIANO RD, MUSTOE TA: Limitations of the $\mathrm{db} / \mathrm{db}$ mouse in translational wound healing research: Is the NONcNZO10 polygenic mouse model superior? Wound Repair Regen 18: 605-613, 2010. https://doi.org/10.1111/j.1524-475X.2010.00634.X

FEDORKO L, BOWEN JM, JONES W, OREOPOULOS G, GOEREE R, ROBERT B HOPKINS RB, O'REILLY DJ: Hyperbaric oxygen therapy does not reduce indications for amputation in patients with diabetes with nonhealing ulcers of the lower limb: A prospective, double-blind, randomized controlled clinical trial. Diabetes Care 39: 392-399, 2016. https://doi.org/10.2337/dc15-2001

GABB G, ROBIN ED: Hyperbaric oxygen - a therapy in search of diseases. Chest 92: 1074-1082, 1987. https://doi.org/10.1378/chest.92.6.1074

GANESH GV, RAMKUMAR KM: Macrophage mediation in normal and diabetic wound healing responses. Inflamm Res 69: 347-363, 2020. https://doi.org/10.1007/s00011-020-01328-y

GOULD LJ, MAY T: The science of hyperbaric oxygen for flaps and grafts. Surg Technol Int 28: 65-72, 2016.

GRADA A, MERVIS J, FALANGA V: Research techniques made simple: Animal models of wound healing. J Invest Dermatol 138: 2095-2105, 2018. https://doi.org/10.1016/j.jid.2018.08.005 
GUO J, CHANG C, LI W: The role of secreted heat shock protein-90 (Hsp90) in wound healing - how could it shape future therapeutics? Expert Rev Proteomics 14: 665-675, 2017. https://doi.org/10.1080/14789450.2017.1355244

GUPTA S, LASKAR N, KADOURI DE: Evaluating the effect of oxygen concentrations on antibiotic sensitivity, growth, and biofilm formation of human pathogens. Microbiol Insights 9: 37-46, 2016. https://doi.org/10.4137/MBI.S40767

GUTTERIDGE JMC: Free radicals in disease processes: a compilation of cause and consequence. Free Radic Res Com 19: 141-158, 1993. https://doi.org/10.3109/10715769309111598

HAN Z, BOYLE DL, CHANG L, BENNETT B, KARIN M, YANG L, MANNING AM, FIRESTEIN GS: c-Jun N-terminal kinase is required for metalloproteinase expression and joint destruction in inflammatory arthritis. J Clin Invest 108 : 73-81, 2001. https://doi.org/10.1172/JCI12466

HOLLANDER DA, HAKIMI MY, HARTMANN A, WILHELM K, WINDOLF J: The influence of hyperbaric oxygenation (HBO) on proliferation and differentiation of human keratinocyte cultures in vitro. Cell Tissue Bank 1: 261-269, 2000. https://doi.org/10.1023/A:1010145312698

HUANG G, XU J, XU L, WANG S, LI R, LIU K: Hyperbaric oxygen preconditioning induces tolerance against oxidative injury and oxygen-glucose deprivation by up-regulating heat shock protein 32 in rat spinal neurons. PLoS One 9: e85967, 2014. https://doi.org/10.1371/journal.pone.0085967

HUANG X, LIANG P, JIANG B, ZHANG P, YU W, DUAN M, GUO L, CUI X, HUANG M, HUANG X: Hyperbaric oxygen potentiates diabetic wound healing by promoting fibroblast cell proliferation and endothelial cell angiogenesis. Life Sci 259: 118246, 2020. https://doi.org/10.1016/j.lfs.2020.118246

ISAACS JS, JUNG YJ, MIMNAUGH EG, MARTINEZ A, CUTTITTA F, NECKERS LM: Hsp90 regulates a von Hippel Lindau-independent hypoxia-inducible factor-1 alpha-degradative pathway. J Biol Chem 277: 29936-29944, 2002. https://doi.org/10.1074/jbc.M204733200

JAIN KK: Textbook of Hyperbaric Medicine. Hogrefe \& Huber Publishers, Gottingen, Germany, 2009, 578 p.

JENSEN PØ, MØLLER SA, LERCHE CJ, MOSER C, BJARNSHOLT T, CIOFU O, FAURHOLT-JEPSEN D, HØIBY N, KOLPEN M: Improving antibiotic treatment of bacterial biofilm by hyperbaric oxygen therapy: Not just hot air. Biofilm 1: 100008, 2019. https://doi.org/10.1016/j.bioflm.2019.100008

JOHNSTON BR, HA AY, BREA B, LIU PY: The mechanism of hyperbaric oxygen therapy in the treatment of chronic wounds and diabetic foot ulcers. R I Med J (2013) 99: 26-29, 2016.

KANG TS, GORTI GK, QUAN SY, HO M, KOCH RJ: Effect of hyperbaric oxygen on the growth factor profile of fibroblasts. Arch Facial Plast Surg 6: 31-35, 2004. https://doi.org/10.1001/archfaci.6.1.31

KINDWALL EP: Hyperbaric Medicine Practice. Best Publishing Company, New York, 1994, $691 \mathrm{p}$.

KOLPEN M, LERCHE CJ, KRAGH KN, SAMS T, KOREN K, JENSEN AS, LINE L, BJARNSHOLT T, CIOFU O, MOSER C, KÜHL M, HØIBY N, JENSEN PØ: Hyperbaric oxygen sensitizes anoxic Pseudomonas aeruginosa biofilm to ciprofloxacin. Antimicrob Agents Chemother 61: e01024-17. 2017. https://doi.org/10.1128/AAC.01024-17

KOOMANACHAI P, KEEL RA, JOHNSON-ARBOR KK, SUECOF LA, NICOLAU DP, KUTI JL: Linezolid penetration into wound tissue of two diabetic patients before and after hyperbaric oxygen therapy. Undersea Hyperb Med 38: 11-16, 2011.

KOPPENOL WH, BUTLER J: Energetics of interconversion reactions of oxyradicals. Adv Free Radical Biol Med 1: 91-131, 1985. https://doi.org/10.1016/8755-9668(85)90005-5

KRANKE, P, BENNETT MH, MARTYN-ST JAMES M, SCHNABEL A, DEBUS SE, WEIBEL S: Hyperbaric oxygen therapy for chronic wounds. Cochrane Database Syst Rev 2015: CD004123, 2015. https://doi.org/10.1002/14651858.CD004123.pub4

KUNNAVATANA SS, QUAN SY, KOCH RJ: Combined effect of hyberbaric oxygen and N-acetylcysteine on fibroblast proliferation. Arch Otolaryngol Head Neck Surg 131: 809-814, 2005. https://doi.org/10.1001/archotol.131.9.809

KURT T, VURAL A, TEMIZ A, OZBUDAK E, YENER AU, SACAR S, SACAR M: Adjunctive hyperbaric oxygen therapy or alone antibiotherapy? Methicillin resistant Staphylococcus aureus mediastinitis in a rat model. Braz J Cardiovasc Surg 30: 538-543, 2015. https://doi.org/10.5935/1678-9741.20150055 
LERCHE CJ, CHRISTOPHERSEN LJ, KOLPEN M, NIELSEN PR, TRØSTRUP H, THOMSEN K, HYLDEGAARD O, BUNDGAARD H, JENSEN PØ, HØIBY N, MOSER C: Hyperbaric oxygen therapy augments tobramycin efficacy in experimental Staphylococcus aureus endocarditis. Int J Antimicrob Agents 50: 406-412, 2017. https://doi.org/10.1016/j.ijantimicag.2017.04.025

LIU R, LI L, YANG M, BODEN G, YANG G: Systematic review of the effectiveness of hyperbaric oxygenation therapy in the management of chronic diabetic foot ulcers. Mayo Clinic Proc 88: 166-175, 2013. https://doi.org/10.1016/j.mayocp.2012.10.021

LIU YV, BAEK JH, ZHANG H, DIEZ R, COLE RN, SEMENZA GL: RACK1 competes with HSP90 for binding to HIF-1alpha and is required for O(2)-independent and HSP90 inhibitor-induced degradation of HIF-1alpha. Mol Cell 25: 207-217, 2007. https://doi.org/10.1016/j.molcel.2007.01.001

LÖNDAHL M, KATZMAN P, NILSSON A, HAMMARLUND C: Hyperbaric oxygen therapy facilitates healing of chronic foot ulcers in patients with diabetes. Diabetes Care 33: 998-1003, 2010. https://doi.org/10.2337/dc09-1754

MA X, WANG F, ZHEN X, ZHAO L, FANG L, DONG Z, CHEN W, ZHOU X: gp91 phox, a novel biomarker evaluating oxidative stress, is elevated in subclinical hypothyroidism. Int J Endocrinol 2020: 3161730, 2020. https://doi.org/10.1155/2020/3161730

MACH WJ, THIMMESCH AR, PIERCE JT, PIERCE JD: Consequences of hyperoxia and the toxicity of oxygen in the lung. Nurs Res Pract 2011: 260482, 2011. https://doi.org/10.1155/2011/260482

MARGOLIS DJ, GUPTA J, HOFFSTAD O, PAPDOPOULOS M, GLICK HA, THOM SR, MITRA N: Lack of effectiveness of hyperbaric oxygen therapy for the treatment of diabetic foot ulcer and the prevention of amputation: a cohort study. Diabetes Care 36: 1961-1966, 2013. https://doi.org/10.2337/dc12-2160

MARTINENGO L, OLSSON M, BAJPAI R, SOLJAK M, UPTON Z, SCHMIDTCHEN A, CAR J, JÄRBRINK K: Prevalence of chronic wounds in the general population: systematic review and meta-analysis of observational studies. Ann Epidemiol 29: 8-15, 2019. https://doi.org/10.1016/j.annepidem.2018.10.005

MASKOS K, BODE W: Structural basis of matrix metalloproteinases and tissue inhibitors of metalloproteinases. Mol Biotechnol 25: 241-266, 2003. https://doi.org/10.1385/MB:25:3:241

MEMAR MY, YEKANI M, ALIZADEH N, BAGHI HB: Hyperbaric oxygen therapy: Antimicrobial mechanisms and clinical application for infections. Biomed Pharmacother 109: 440-447, 2019. https://doi.org/10.1016/j.biopha.2018.10.142

MENDEL V, REICHERT B, SIMANOWSKI HJ, SCHOLZ HC: Therapy with hyperbaric oxygen and cefazolin for experimental osteomyelitis due to Staphylococcus aureus in rats. Undersea Hyperb Med 26: 169-174, 1999.

MINET E, MOTTET D, MICHEL G, ROLAND I, RAES M, REMACLE J, MICHIELS C: Hypoxia-induced activation of HIF-1: role of HIF-1alpha-Hsp90 interaction. FEBS Lett 460: 251-256, 1999. https://doi.org/10.1016/S0014-5793(99)01359-9

MODARRESSi A, PIETRAMAGGIORI G, GODBOUT C, VIGATO E, PITTET B, HINZ B: Hypoxia impairs skin myofibroblast differentiation and function. $\mathrm{J}$ Invest Dermatol 130: 2818-2827, 2010. https://doi.org/10.1038/jid.2010.224

MONTRIEF T, LONG B, KOYFMAN A, AUERBACH J: Fournier gangrene: A review for emergency clinicians. J Emerg Med 57: 488-500, 2019. https://doi.org/10.1016/j.jemermed.2019.06.023

NI XX, NI M, FAN DF, SUN Q, KANG ZM, CAI ZY, LIU Y, LIU K, LI RP, XU WG: Heat-shock protein 70 is involved in hyperbaric oxygen preconditioning on decompression sickness in rats. Exp Biol Med (Maywood) 238: 12-22, 2013. https://doi.org/10.1258/ebm.2012.012101

PAN S, BAI X, WANG F, JIANG M, WANG G, SUN B, KONG R, GUO Z, ZHOU Y, SONG Z: The apoptosis of peripheral blood lymphocytes promoted by hyperbaric oxygen treatment contributes to attenuate the severity of early stage acute pancreatitis in rats. Apoptosis 19: 58-75, 2013. https://doi.org/10.1007/s10495-013-0911-X

PEREIRA AL, FERREIRA MR, SANTOS OJ, SAUAIA FILHO EN, PAIVA AE, SANTOS RH, SANTOS RA: Effects of oxygen in lungs of rats. Acta Cir Bras 29: 771-775, 2014. https://doi.org/10.1590/S0102-86502014001900001

PISOSCHI, AM, POP A: The role of antioxidants in the chemistry of oxidative stress - review. Eur J Med Chem 97: 55-74, 2015. https://doi.org/10.1016/j.ejmech.2015.04.040 
PLACE TL, DOMANN FE, CASE AJ: Limitations of oxygen delivery to cells in culture: An underappreciated problem in basic and translational research. Free $\operatorname{Rad}$ Biol Med 113: 311-322, 2017. https://doi.org/10.1016/j.freeradbiomed.2017.10.003

POFF A, D'AGOSTINO DP, KERNAGIS DN: Hyperbaric environment: Oxygen and cellular damage versus protection. Compr Physiol 7: 213-234, 2016. https://doi.org/10.1002/cphy.c150032

PRATT WB: The role of the hsp90-based chaperone system in signal transduction by nuclear receptors and receptors signaling via MAP kinase. Annu Rev Pharmacol Toxicol 37: 297-326, 1997. https://doi.org/10.1146/annurev.pharmtox.37.1.297

RAHIM K, SALEHA S, ZHU X, HUO L, BASIT A, FRANCO OL: Bacterial contribution in chronicity of wounds. Microb Ecol 73: 710-721, 2017. https://doi.org/10.1007/s00248-016-0867-9

RASMUSSEN A, ALMDAL T, ANKER NIELSEN A, NIELSEN KE, JØRGENSEN ME, HANGAARD S, SIERSMA V, HOLSTEIN PE: Decreasing incidence of foot ulcer among patients with type 1 and type 2 diabetes in the period 2001-2014. Diabetes Res Clin Pract 130: 221-228, 2017. https://doi.org/10.1016/j.diabres.2017.05.025

RINALDI B, CUZZOCREA S, DONNIACUO M, CAPUANO A, DI PALMA D, IMPERATORE F, MAZZON E, DI PAOLA R, SODANO L, ROSSI F: Hyperbaric oxygen therapy reduces the toll-like receptor signaling pathway in multiple organ failures. Intensive Care Med 37: 1110-1119, 2011. https://doi.org/10.1007/s00134-011-2241-1

SANTEMA KTB, STOEKENBROEK RM, KOELEMAY MJW, REEKERS JA, VAN DORTMONT LMC, OOMEN A, SMEETS L, WEVER JJ, LEGEMATE DA, UBBINK DT: DAMO2CLES Study Group - Hyperbaric Oxygen Therapy in the Treatment of Ischemic Lower- Extremity Ulcers in Patients With Diabetes: Results of the DAMO2CLES Multicenter Randomized Clinical Trial. Diabetes Care 41: 112-119, 2018. https://doi.org/10.2337/dc17-0654

SANTORO MG: Heat shock factors and the control of the stress response. Biochem Pharmacol 59: 55-63, 2000. https://doi.org/10.1016/S0006-2952(99)00299-3

SCHIEBER M, CHANDEL SN: ROS function in redox signaling and review oxidative stress. Curr Biol 24: R453-R462, 2014. https://doi.org/10.1016/j.cub.2014.03.034

SEMENZA GL: Hypoxia-inducible factor 1: master regulator of O2 homeostasis. Curr Opin Genet Dev 8: 588-594, 1998. https://doi.org/10.1016/S0959-437X(98)80016-6

SLIMEN IB, NAJAR T, GHRAM A, DABBEBI H, BEN MRAD M, ABDRABBAH M: Reactive oxygen species, heat stress and oxidative-induced mitochondrial damage. A review. Int J Hyperthermia 30: 513-523, 2014. https://doi.org/10.3109/02656736.2014.971446

SNOEK-VAN BEURDEN PAM, VON DEN HOFF JW: Zymographic techniques for the analysis of matrix metalloproteinases and their inhibitors. BioTechniques 38: 73-83, 2005. https://doi.org/10.2144/05381RV01

STOEKENBROEK RM, SANTEMA TB, LEGEMATE DA, UBBINK DT, VAN DEN BRINK A, KOELEMAY MJW: Hyperbaric oxygen for the treatment of diabetic foot ulcers: a systematic review. Eur J Vasc Endovasc Surg 47: 647-655, 2014. https://doi.org/10.1016/j.ejvs.2014.03.005

STOWE DF, CAMARA AKS: Mitochondrial reactive oxygen species production in excitable cells: modulators of mitochondrial and cell function. Antioxid Redox Signal 11: 1373-1405, 2009. https://doi.org/10.1089/ars.2008.2331

SUNKARI VG, LIND F, BOTUSAN IR, KASHIF A, LIU ZJ, YLÄ-HERTTUALA S, BRISMAR K, VELAZQUEZ O, CATRINA SB: Hyperbaric oxygen therapy activates hypoxia-inducible factor 1 (HIF-1), which contributes to improved wound healing in diabetic mice. Wound Repair Regen 23: 98-103, 2015. https://doi.org/10.1111/wrr.12253

TAKUBO K, GODA N, YAMADA W, IRIUCHISHIMA H, IKEDA E, KUBOTA Y, SHIMA H, JOHNSON RS, HIRAO A, SUEMATSU M, SUDA T: Regulation of the HIF-1alpha level is essential for hematopoietic stem cells. Cell Stem Cell 7: 391-402, 2010. https://doi.org/10.1016/j.stem.2010.06.020

THOM SR: Oxidative stress is fundamental to hyperbaric oxygen therapy. J Appl Physiol 106: 988-995, 2009. https://doi.org/10.1152/japplphysiol.91004.2008

THOMSON L, PATON J: Oxygen toxicity. Paediatr Respir Rev 15: 120-123, 2014. https://doi.org/10.1016/j.prrv.2014.03.003 
TRAN NH, FROST JA: Phosphorylation of Raf-1 by p21-activated kinase 1 and Src regulates Raf-1 autoinhibition. J Biol Chem 278: 11221-11226, 2003. https://doi.org/10.1074/jbc.M210318200

WAGNER BA, VENKATARAMAN S, BUETTNER GR: The rate of oxygen utilization by cells. Free Rad Biol Med 51: 700-712, 2011. https://doi.org/10.1016/j.freeradbiomed.2011.05.024

WEISZ G, LAVY A, ADIR Y, MELAMED Y, RUBIN D, EIDELMAN S, POLLACK S: Modification of in vivo and in vitro TNF-alpha, IL-1, and IL-6 secretion by circulating monocytes during hyperbaric oxygen treatment in patients with perianal Crohn's disease. J Clin Immunol 17: 154-159, 1997. https://doi.org/10.1023/A:1027378532003

WILKINSON D, DOOLETTE D: Hyperbaric oxygen treatment and survival from necrotizing soft tissue infection. Arch Surg 139: 1339-1345, 2004. https://doi.org/10.1001/archsurg.139.12.1339

WU HH, NIU KC, LIN CH, LIN HJ, CHANG CP, WANG CT: HSP-70-mediated hyperbaric oxygen reduces brain and pulmonary edema and cognitive deficits in rats in a simulated high-altitude exposure. Biomed Res Int 2018: 4608150, 2018. https://doi.org/10.1155/2018/4608150

XU X, WANG Z, LI Q, XIAO X, LIAN Q, XU W, SUN X, TAO H, LI R: Endothelial nitric oxide synthase expression is progressively increased in primary cerebral microvascular endothelial cells during hyperbaric oxygen exposure. Oxid Med Cell Longev 2: 7-13, 2009. https://doi.org/10.4161/oxim.2.1.7697

YANG S, LIAN G: ROS and diseases: Role in metabolism and energy supply. Mol Cell Biochem 467: 1-12, 2020. https://doi.org/10.1007/s11010-019-03667-9

ZEPEDA AB, PESSOA A JR, CASTILLO RL, FIGUEROA CA, PULGAR VM, FARÍAS JG: Cellular and molecular mechanisms in the hypoxic tissue: role of HIF-1 and ROS. Cell Biochem Funct 31: 451-459, 2013. https://doi.org/10.1002/cbf.2985

ZHANG Q, GOULD LJ: Hyperbaric oxygen reduces matrix metalloproteinases in ischemic wounds through a redoxdependent mechanism. J Investigat Dermatol 134: 237-246, 2013. https://doi.org/10.1038/jid.2013.301 